\title{
Assessment of Respiratory and Pulmonary Functions of Glass Blowers
}

\author{
Sonia Tewari* and Deepa Vinay \\ Department of Family Resource Management, College of Home Science, GB Pant University \\ of Agriculture and Technology, Pantnagar, Uttarakhand, India \\ *Corresponding author
}

\section{A B S T R A C T}

\section{Keywords}

Blowers, Glass Industry, Pulmonary function, Respiratory, Spirometry

Article Info

Accepted: 15 December 2020 Available Online: 10 January 2021
Glass Industry workers use to blow the glass so that desired shape can be achieved and this task of blowing requires certain amount of pressure from the lungs. So, to assess the respiratory and pulmonary functions among blowers of the glass manufacturing unit, 30 glass blowers and 30 non-glass blowers were selected for spirometry using medspiror and 120 workers selected randomly from manufacturing unit to assess the subjective symptoms of respiratory problems using checklist. The result of subjective analysis shows that majorly reported respiratory problems among workers were cough $(49.17 \%)$, body ache $(38.33 \%)$ and chest pain $(32.50 \%)$ Observations of spirometry revealed a positive and significant correlation between FEV1(r=0.402), PEFR(r=0.387) and weight. Among glass blowers and non blowers group, significant difference was found for the means values of FEV1 \% predicted (0.032) and FEF 25-75\% measured (0.003) and FEF 25-75\% predicted $\%(0.018)$ at $5 \%$ level of significance and also noteworthy variation was found in FEV1 measured (0.026), FEV1 predicted (0.016), FEF25-75 measured (0.018), FEF25-75 predicted $(0.047)$ at $5 \%$ level of significance among these group.

\section{Introduction}

Glass manufacturing industries are growing with a rapid pace. It involves various types of task which are performed by the workers and classified as skilled task. Since the beginning of civilization, human beings have evolved their standard of living with the discovery of new elements and their combinations. One such miraculous chemical compound is glass. With the advent of time, it has evolved as one of the most widely used material and has occupied an indispensable place in our dayto-day life.
Glass manufacturing sector has also witnessed tremendous changes in term of growth and expansion (Wintour, 2015). Although being informal in nature, glass industries are more diverse and less systematic in their approach; its great share in the economies cannot be undermined.

In the context of India, glass industries hold a lion share in industrial growth in terms of production, several establishments units, the involvement of large share of the skilled, unskilled and semi-skilled labour force. At present, about 3.5 lakhs of different types of 
glasses are produced by glass industries throughout the world (Douglas, 2018).

Glass making is a very tiresome process and require so much of expertise. Glass blowing is a very old and treasured art when artisans use their special kind of skill to produces articles made from glass for commercial or artistic purpose. The process involves blowing of blowing molten glass manually. This blowing task puts pressures on lungs. The molten glass was gathered first from the furnace with the help of a long hollow blowpipe made up of metal and delivers the first puff of air through the pipe from mouth so that molten glass should be expanded by blowing. The blowpipe is then handed over to the master glass blower who continues to expand and shape the glass by means of positive pressure produced by careful, controlled oral expiration. The oral pressures generated are small and continuous in a way that it produces a steady expansion of the molten glass before it gets cool (Munn et al, 1990). The workers were directly and indirectly exposed to various kinds of in occupational hazards.

Barbara listed various hazards in workplace faced by glass blowers. They are respiratory problems, heat stress, burns and cuts and ergonomic hazards. Among these hazards respiratory hazards was due to the inhalation of the fumes and particulate matters of the material used in glass making. Asbestos tapes and some minerals substance that beatify glass by imparting colour are very much toxic in nature regardless of how they are ingested in body. These workers were exposed to the salts of various heavy metals, such as arsenic, lead, zinc, copper, manganese, cobalt, cadmium, and selenium, which are used as coloring agents (Rastogi et al., 1991). Occupational exposures to dust, fumes, and gases are associated with increased prevalence of respiratory symptoms and impairment of lung function. Winsor (2015) argued that apart from the general hazards such as heat and noise exposure, respiratory and physical hazards, there are psychosocial and physical environment impacts of such manufacturing units on the worker. Zuskin et al (1993) commented that working in the glassblowing industry contributes to the development of respiratory symptoms such as chronic bronchitis, nasal catarrh, sinusitis, and nasal bleeding. According to a case study of Firozabad glass industry by Agarwal and Varshney (2014) on health and environmental impacts of glass industry, it was found that the high prevalence of chronic bronchitis in the glass bangle industry was the result of long-term exposure to pollutants emitted during the manufacturing process. The reason reported by the authors) male workers do work in large scale production units from their early ages and due to direct contact with hazardous working conditions. They suffer from aggravated asthma and chronic bronchitis, tuberculosis, lung cancer, epidemiological disorders, skin allergy, eye burns damage of liver and kidney, cough and lastly premature death. Amira Jamoussi et al., (2018) diagnosed one case of fatal Chronic beryllium disease (CBD) in glass industry where a man of 27 years were exposed to beryllium. IARC and Robertson mentioned that due to inhalation of inorganic dust like asbestos or silica glassblowing workers were having lung diseases are pneumoconiosis. As workers were also affected by the heat stress as they work nearby the furnace where glass is melted at $15000^{\circ} \mathrm{C}$ (Brahmapurkar et al., (2013). So, there are chances to develop respiratory problems as Haines et al., (2006) in their study on climate change and human health reported that the susceptibility of the person with respiratory, cardiovascular disease and or Cerebro-vascular diseases was increased mainly by heat. Areas that are not affected by heat waves now days will be impacted by changing patterns of climate, frequent heat episodes in the near future. 
Zuskin, E. et al.(1993) in their study on Respiratory function in workers employed in the glass blowing industry measured the lung function among glassblowers and found that there were significant increases in the forced vital capacity (FVC) and the maximum flow rates at 50 percent and 25 percent of $\mathrm{FVC}$ on maximum expiratory flow volume(MEFV) curves (FEF50, FEF25) across glass shift. Glass blowers had significantly larger preshift FVC and forced expiratory volume in 1second (FEV1) measurements when compared to controls. The mean values of FVC, FEV1, IMBC, and PEFR were within the normal range (more than 80 percent of the predicted values) in both smoking and non smoking glass bangle workers and also did not show any significant differences in the unexposed controls as well. However, significant $(\mathrm{p}<0.001)$ reduction was found in the exposed group on variables such as FEV1/FVC percent ratio, FEF25-75 and FEF75-85. When compared to the controlled group (7.9 \%), a significantly higher prevalence $(16.3 \%)$ of respiratory impairment was found in the exposed group as a result of exposure to various metals in the work environment $(\mathrm{p}<0.01)$. The restrictive pattern of pulmonary abnormality (10.4\%), were observed in the exposed group while the controls revealed only 1.1 percent prevalence of this disease $(\mathrm{p}<0.001)$. It was clearly indicated from the results that the duration of exposure is directly related to the prevalence of respiratory impairment. As results revealed a significantly higher prevalence of respiratory impairment $(\mathrm{p}<0.05)$ in the case who worked for more than 10 years $(23.0 \%)$ than in those who worked for less than 10 years (10.8\%) Rastogi et al.(1991). Dhule et al.(2013) conducted their study on the topic of pulmonary function tests in wind instrument players in which it was assumed that the wind instruments playing have been associated with changes in respiratory function. The objective was to study the effect of playing wind instruments on lung function. The sample includes 30 wind instruments players and 30 normal subjects not playing any wind instrument. The results of the study significantly increased the level of FVC, PEFR, MVV and lower FEV1 percent among wind instruments players than in the control group. So, he concluded that wind instrument players had higher lung function. A significant reduction in the mean values of Forced Vital Capacity (FVC), Forced Expiratory Volume in one second (FEV1), Forced Expiratory Ratio (FEV1/FVC), Forced Expiratory Flow (25 percent-75 \%) and Peak Expiratory Flow Rate (PEFR) found in bangle workers of glass factory workers relative to their matched controls. As the duration of exposure to fumes in bangle industries increases, the impairment was also observed to be increased. (Sant et al., 2014).

This bowing task also leads to alteration in the respiratory functions of the blowers. So keeping in mind the blowing task, the study was designed with the objective of assessment of respiratory and pulmonary changes among blowers.

\section{Materials and Methods}

The present study was carried out in Uttar Pradesh at the glass manufacturing industry. Purposive and random sampling technique was used to select the study area and sample. 30 blowers and 30 non blowers were selected for the experimental study. Checklist for subjective symptoms of respiratory problems was used and for spirometry as experimental part Med Spiormeter was used. The statistical analyses used were t-test, F-test and corelation.

\section{Results and Discussion}

The results of the study were described under following sub-headings: 


\section{Respiratory problems of the workers}

As there are chances of having respiratory health issues, the subjective symptoms of the respiratory problems faced by workers based on the multiple responses revealed that the major respiratory problems among glass manufacturing workers were cough reported by 49.17 percent, body ache $(38.33 \%)$, chest pain $(32.50 \%)$, and dry, scratchy or sore throat $(30.83 \%)$. The other problems were fever (21.67\%), tight chest (20.83\%), abnormal breathing (11.66\%), wheezing (10 $\%)$, running nose and chronic sinusitis (5.83 $\%$ ), and only 3.33 percent reported a problem of chronic bronchitis whereas 33.33 percent do not report any respiratory problems. In comparisons to ball makers, mold handlers and helpers, blowers have a high prevalence rate of cough $(62.16 \%)$, chest pain (56.75), dry, scratchy or sore throat $(48.64 \%)$, body aches $(45.94 \%)$. The other reported problems were tight chest $(32.43 \%)$,

A study conducted by Yingratanasuk et al., (2002) on stone carvers in Thailand also reported the most common respiratory symptom in the carvers was phlegm $(26.8 \%)$, followed by cough, dyspnea, chronic bronchitis, and wheeze (16.5 percent, 12.4 percent, 6.2 percent, and 4.1 percent, respectively). Mortar makers at Location II and III also reported a high prevalence of phlegm (42.1 percent and 50 percent, respectively).

Pulmonary functions of the blowers and non-blowers

A vital lung capacity test was conducted to identify the pulmonary changes among glass manufacturing unit workers. The test was conducted to find out the difference of vital lung capacity parameters among blowers as an experimental group and non-blowers taken as a controlled group. The factors that were considered for the lung capacity were age, height, weight, and BMI. It is evident from table 2 that the mean age and SD was found to be $36.63 \pm 7.38$ years for blowers and $33.90 \pm 9.10$ years for the non-blowers. The mean height and mean weight of blowers were $166.97 \pm 7.36 \mathrm{~cm}$ and $61.67 \pm 11.09 \mathrm{~kg}$ while non-blowers were having a mean height of $164.00 \pm 7.27 \mathrm{~cm}$ and mean weight of $58.77 \pm 8.17 \mathrm{~kg}$. The BMI of the blowers were $22.09 \pm 3.40 \mathrm{~kg} / \mathrm{m} 2$ and non-blowers were $21.85 \pm 2.74 \mathrm{~kg} / \mathrm{m} 2$. The mean age of the glass blowers was found to be similar 34 years (range: 21-54 years) and their mean height was $171 \mathrm{~cm}$ which was similar to the study conducted by Zuskin et al., (1993).

\section{Difference between the mean values of the pulmonary functions test among blowers and non-blowers}

Table 3 reveals the pulmonary test results of the blowers and controlled group (nonblowers). The t-value was calculated and the significance difference was found to be in FEV1 \% predicted (0.032) and Forced expiratory flow at $25-75 \%$ measured $(0.003)$ and FEF $25-75 \%$ predicted $\%(0.018)$ at $5 \%$ level of significance whereas no difference was found in the mean values of FVC measured, FVC predicted, FEV1 measured, PEFR measured, PEFR predicted, FEV1/FVC measured and FEV1/FVC predicted among blowers and non blowers.

The study conducted by Sant et al., (2014) on glass factory workers found to be have contradictory results compared to the present study. In their study FEV1 and FVC, ratio FEV1/FVC\% was significantly reduced in study groups (glass bangle industry workers) then the control groups. The flow rate PEFR decreased much significantly in bangle industry workers as compared to controls. No significant change was observed in FEF 25\%$75 \%$ in subjects and control group. 
Table.1 Respiratory problems reported subjectively by the workers

\begin{tabular}{|c|c|c|c|c|c|c|}
\hline $\begin{array}{l}\text { S.N } \\
\text { o. }\end{array}$ & Respiratory Problems* & $\begin{array}{l}\text { Ball } \\
\text { maker } \\
\text { n1=34 }\end{array}$ & $\begin{array}{c}\text { Ball } \\
\text { blower } \\
\text { n2=37 }\end{array}$ & $\begin{array}{c}\text { Mold } \\
\text { handlers } \\
\text { n3=26 }\end{array}$ & $\begin{array}{l}\text { Helper } \\
\text { n4=23 }\end{array}$ & $\begin{array}{c}\text { Total } \\
\text { N=120 }\end{array}$ \\
\hline 1. & Not reported & $\begin{array}{c}7 \\
(20.58)\end{array}$ & $\begin{array}{c}11 \\
(29.72)\end{array}$ & $\begin{array}{c}5 \\
(19.23)\end{array}$ & $\begin{array}{c}17 \\
(73.91)\end{array}$ & $\begin{array}{c}40 \\
(33.33)\end{array}$ \\
\hline 2. & Cough & $\begin{array}{c}12 \\
(35.29)\end{array}$ & $\begin{array}{c}23 \\
(62.16)\end{array}$ & $\begin{array}{c}20 \\
(76.92)\end{array}$ & $\begin{array}{c}4 \\
(17.39)\end{array}$ & $\begin{array}{c}59 \\
(49.17)\end{array}$ \\
\hline 3. & $\begin{array}{l}\text { Wheezing (to breath loudly } \\
\text { (making sound) and with } \\
\text { difficulty) }\end{array}$ & $\begin{array}{c}3 \\
(8.82)\end{array}$ & $\begin{array}{c}4 \\
(10.81)\end{array}$ & $\begin{array}{c}2 \\
(7.69)\end{array}$ & $\begin{array}{c}3 \\
(13.04)\end{array}$ & $\begin{array}{c}12 \\
(10.00)\end{array}$ \\
\hline 4. & $\begin{array}{l}\text { Chronic bronchitis (coughing } \\
\text { and difficulty in breathing) }\end{array}$ & - & $\begin{array}{c}4 \\
(10.81)\end{array}$ & - & - & $\begin{array}{c}4 \\
(3.33)\end{array}$ \\
\hline 5. & $\begin{array}{l}\text { Nasal catarrh (blocked and } \\
\text { stuffy nose) }\end{array}$ & - & $\begin{array}{c}6 \\
(16.21)\end{array}$ & $\begin{array}{c}2 \\
(7.69)\end{array}$ & $\begin{array}{c}3 \\
(13.04)\end{array}$ & $\begin{array}{c}11 \\
(9.17)\end{array}$ \\
\hline 6. & Chronic sinusitis (sinus) & - & $\begin{array}{c}2 \\
(5.40)\end{array}$ & $\begin{array}{c}5 \\
(19.23)\end{array}$ & - & $\begin{array}{c}7 \\
(5.83)\end{array}$ \\
\hline 7. & Dry, scratchy, or sore throat & $\begin{array}{c}11 \\
(32.35)\end{array}$ & $\begin{array}{c}18 \\
(48.64)\end{array}$ & $\begin{array}{c}8 \\
(30.76)\end{array}$ & - & $\begin{array}{c}37 \\
(30.83)\end{array}$ \\
\hline 8. & Runny nose & $\begin{array}{c}1 \\
(2.94)\end{array}$ & $\begin{array}{c}6 \\
(16.21)\end{array}$ & - & - & $\begin{array}{c}7 \\
(5.83)\end{array}$ \\
\hline 9. & Fever & $\begin{array}{c}5 \\
(14.70)\end{array}$ & $\begin{array}{c}18 \\
(48.64)\end{array}$ & $\begin{array}{c}2 \\
(7.69)\end{array}$ & $\begin{array}{c}1 \\
(4.34)\end{array}$ & $\begin{array}{c}26 \\
(21.67)\end{array}$ \\
\hline 10. & Tight chest & $\begin{array}{c}5 \\
(14.70)\end{array}$ & $\begin{array}{c}12 \\
(32.43)\end{array}$ & $\begin{array}{c}4 \\
(15.38)\end{array}$ & $\begin{array}{c}4 \\
(13.04)\end{array}$ & $\begin{array}{c}25 \\
(20.83)\end{array}$ \\
\hline 11. & Chest Pain & $\begin{array}{c}10 \\
(29.41)\end{array}$ & $\begin{array}{c}21 \\
(56.75)\end{array}$ & $\begin{array}{c}4 \\
(15.38)\end{array}$ & $\begin{array}{c}4 \\
(13.04)\end{array}$ & $\begin{array}{c}39 \\
(32.50)\end{array}$ \\
\hline 12. & Body aches & $\begin{array}{c}10 \\
(29.41)\end{array}$ & $\begin{array}{c}17 \\
(45.94)\end{array}$ & $\begin{array}{c}16 \\
(61.53)\end{array}$ & $\begin{array}{c}3 \\
(13.04)\end{array}$ & $\begin{array}{c}46 \\
(38.33)\end{array}$ \\
\hline 13. & $\begin{array}{l}\text { Breathing problems, such as } \\
\text { shortness of breath or } \\
\text { abnormal breathing. }\end{array}$ & $\begin{array}{c}1 \\
(2.94)\end{array}$ & $\begin{array}{c}6 \\
(16.21)\end{array}$ & $\begin{array}{c}7 \\
(26.92)\end{array}$ & - & $\begin{array}{c}14 \\
(11.66)\end{array}$ \\
\hline 14. & Tight chest & $\begin{array}{c}5 \\
(14.70)\end{array}$ & $\begin{array}{c}12 \\
(32.43)\end{array}$ & $\begin{array}{c}4 \\
(15.38)\end{array}$ & $\begin{array}{c}4 \\
(13.04)\end{array}$ & $\begin{array}{c}25 \\
(20.83)\end{array}$ \\
\hline
\end{tabular}

Note: *Multiple responses

Values in the parenthesis represent percent

Table.2 Descriptive statistics of age, height, weight, and BMI of the blowers and non blowers $\mathrm{n}^{*}=30$

\begin{tabular}{|l|c|c|}
\hline Parameters & $\begin{array}{c}\text { Blowers } \\
(\text { Mean } \pm \text { SD })\end{array}$ & $\begin{array}{c}\text { Non-blowers } \\
\text { (Mean } \pm \text { SD) }\end{array}$ \\
\hline Age $(\mathbf{y r})$ & $36.63 \pm 7.38$ & $33.90 \pm 9.10$ \\
\hline Height $(\mathbf{c m})$ & $166.97 \pm 7.36$ & $164.00 \pm 7.27$ \\
\hline Weight $(\mathbf{k g})$ & $61.67 \pm 11.09$ & $58.77 \pm 8.17$ \\
\hline BMI $(\mathbf{k g} / \mathbf{m} 2)$ & $22.09 \pm 3.40$ & $21.85 \pm 2.74$ \\
\hline
\end{tabular}


Table.3 t-values to compare the mean values of predicted percentage and measured values of pulmonary function parameters of blowers and non-blowers $n^{*}=30$

\begin{tabular}{|l|l|l|l|l|}
\hline Parameters & $\begin{array}{l}\text { Blowers } \\
(\text { Mean } \pm \text { SD })\end{array}$ & $\begin{array}{l}\text { Non-blowers } \\
(\text { Mean } \pm \text { SD })\end{array}$ & t-value & p-value \\
\hline FVC measured & $1.98 \pm 0.76$ & $2.24 \pm 0.87$ & -1.21 & 0.230 \\
\hline FVC \%Predicted & $58.43 \pm 21.15$ & $68.66 \pm 24.76$ & -1.721 & .091 \\
\hline FEV1 measured & $1.39 \pm 0.59$ & $1.76 \pm 0.91$ & -1.875 & 0.066 \\
\hline FEV1 \%Predicted & $49.60 \pm 19.06$ & $64.10 \pm 30.58$ & 0.016 & $0.032^{*}$ \\
\hline PEFR measured & $3.46 \pm 1.94$ & $3.83 \pm 2.08$ & -0.73 & 0.470 \\
\hline PEFR \%Predicted & $39.23 \pm 20.95$ & $43.83 \pm 23.21$ & -0.806 & 0.424 \\
\hline FEF 25-75 measured & $1.41 \pm 0.68$ & $2.22 \pm 1.26$ & -3.112 & $0.003^{*}$ \\
\hline FEF25-75 \%Predicted & $35.33 \pm 17.25$ & $53.20 \pm 28.08$ & -2.968 & $.004^{*}$ \\
\hline FEV1/FVC measured & $71.78 \pm 19.79$ & $78.26 \pm 23.14$ & -1.164 & 0.249 \\
\hline FEV1/FVC \%Predicted & $86.76 \pm 24.07$ & $92.06 \pm 26.45$ & -0.812 & 0.420 \\
\hline
\end{tabular}

*Significant at $5 \%$ level of significance

Table. 4 F- values of predicted percentage and measured values of pulmonary function parameters of blowers and non-blowers $n^{*}=30$

\begin{tabular}{|l|c|c|c|c|}
\hline Parameters & $\begin{array}{c}\text { Blowers } \\
(M e a n \pm \text { SD })\end{array}$ & $\begin{array}{c}\text { Non-blowers } \\
(M e a n \pm \text { SD })\end{array}$ & F value & p-value \\
\hline FVC measured & $1.98 \pm 0.76$ & $2.24 \pm 0.87$ & 0.018 & 0.895 \\
\hline FVC \%Predicted & $58.43 \pm 21.15$ & $68.66 \pm 24.76$ & 0.353 & 0.555 \\
\hline FEV1 measured & $1.39 \pm 0.59$ & $1.76 \pm 0.91$ & 5.252 & $0.026^{*}$ \\
\hline FEV1 \%Predicted & $49.60 \pm 19.06$ & $64.10 \pm 30.58$ & 6.148 & $0.016^{*}$ \\
\hline PEFR measured & $3.46 \pm 1.94$ & $3.83 \pm 2.08$ & 0.547 & 0.463 \\
\hline PEFR \%Predicted & $39.23 \pm 20.95$ & $43.83 \pm 23.21$ & 0.722 & 0.399 \\
\hline FEF 25-75 measured & $1.41 \pm 0.68$ & $2.22 \pm 1.26$ & 5.977 & $0.018^{*}$ \\
\hline FEF25-75 \%Predicted & $35.33 \pm 17.25$ & $53.20 \pm 28.08$ & 4.11 & $0.047^{*}$ \\
\hline FEV1/FVC measured & $71.78 \pm 19.79$ & $78.26 \pm 23.14$ & 0.578 & 0.450 \\
\hline FEV1/FVC \%Predicted & $86.76 \pm 24.07$ & $92.06 \pm 26.45$ & 0.168 & 0.683 \\
\hline
\end{tabular}

*Significant at $5 \%$ level of significance

Table.5 Pearson's correlation value (r) for height, age and weight with the pulmonary lung function parameters $n^{*}=30$

\begin{tabular}{|c|c|c|c|c|}
\hline Parameters & Values & Height & Age & Weight \\
\hline \multirow[t]{2}{*}{ FVC } & $\mathbf{r}$ & 0.206 & -0.9 & 0.251 \\
\hline & p value & 0.275 & 0.638 & 0.181 \\
\hline \multirow[t]{2}{*}{ FEV1 } & $\mathbf{r}$ & 0.321 & -0.177 & $0.402 *$ \\
\hline & p value & 0.083 & 0.35 & 0.027 \\
\hline \multirow[t]{2}{*}{ PEFR } & $\mathbf{r}$ & 0.357 & -0.129 & $0.387 *$ \\
\hline & $p$ value & 0.053 & 0.496 & 0.035 \\
\hline \multirow[t]{2}{*}{ FEF 25-75 } & $\mathbf{r}$ & 0.279 & -0.123 & 0.356 \\
\hline & p value & 0.136 & 0.518 & 0.053 \\
\hline \multirow[t]{2}{*}{ FEV1/FVC } & $\mathbf{r}$ & 0.054 & -0.045 & 0.157 \\
\hline & p value & 0.775 & 0.813 & 0.406 \\
\hline
\end{tabular}

*Significant at $5 \%$ level of significance 
Variation in lung function parameters between the Blower and Non-blowers

The F-test was used. Table 4 elucidates that at $5 \%$ level of significance, significant variation was found in FEV1 measured (0.026), FEV1 predicted (0.016), FEF25-75 measured (0.018), FEF25-75 predicted (0.047) while variation was found to be same FVC measured, FVC $\%$ predicted, PEFR measured, PEFR \%predicted, FEV1/FVC \% measured and FEV1/FVC $\%$ predicted of the experimental and controlled group. The result of the present study found to be similar in the case of flour mill workers in which $\mathrm{FVC} \%$ predicted and FEV1/FVC measured between subjects and this was statistically significant (Melo et al, 2016).

\section{Correlation of height, age and weight with} the pulmonary lung function parameters

The results of the Pearson's correlation were shown in table 4.54 which revealed that FEV 1 $(\mathrm{r}=0.402)$ and PEFR $(\mathrm{r}=0.387)$ as positively and significantly related to weight. While FVC, FEF 25-75 and FEV1/FVC were found to be positively correlated with the weight but no significance was found for the same. The FVC, FEV1, PEFR, FEF 25-75 and FEV1/FVC were found to be positively correlated but not significantly. But in case of age, the pulmonary lung function parameters viz. FVC, FEV1, PEFR, FEF 25-75 and FEV1/FVC found to be negatively correlated without any significance.

The present study concludes that the major respiratory problems among glass making workers found to be of cough $(49.17 \%)$, body ache $(38.33 \%)$, chest pain $(32.50 \%)$, and dry, scratchy or sore throat (30.83\%). Among experimental and control group, a significant difference was found for the means values of FEV1 $\%$ predicted and forced expiratory flow at $25-75 \%$ measured and FEF $25-75 \%$ predicted $\%$ at $5 \%$ level of significance. Between the experimental and control group, significant variation was found in FEV1 measured, FEV1 predicted, FEF25-75 measured, FEF25-75 predicted at $5 \%$ level of significance.

\section{Acknowledgment}

Heartiest Thanks to University Grant Commission for providing the financial assistance in the form of UGC-NET JRF Fellowship.

\section{References}

Agarwal, P. and Varshney, S. 2014. Health and Environmental Impacts of Glass Industry (A Case Study of Firozabad Glass Industry). European Academic Research. 2(8): 10127: 10149.

Barbara Hazelden. Workplace Hazards in Glass Blowing. https://smallbusiness.chron.com/workpl ace-hazards-glass-blowing-11988.html

Brahmapurkar, K.P. et al.2013. Morbidities in the Glass Factory Workers of Central India. IOSR Journal of Dental and Medical Sciences (IOSR-JDMS).7(6): 29-33. e-ISSN: 2279-0853, p-ISSN: 2279-0861.

Dhule, S.S., Bisht,S.N. and Gawali, S.R. 2013. Pulmonary function tests in wind instrument players. International Journal of Science and Research (IJSR). 2(5): 384:386.

Douglas,M.2018. Humankind's Most Important Material. The Atlantic. https://www.theatlantic.com/technolog y/archive/2018/04/humankinds-mostimportant-material/557315/

Haines, A., Kovats, S., Campbell-Lendrum, D. and Corvalan, C. 2006. Climate Change and Human Health: Impacts, Vulnerability and Public Health. Public health. $\quad 120$ : $\quad 585-96$. 
10.1016/j.puhe.2006.01.002.

International Agency for Research on Cancer working group. Beryllium, Cadmium, Mercury, and exposures in the glass manufacturing industry. 1993; 58. PubMed

Melo, C.A., Konda, S.G., Shah, T. and Padwale Y. 2016. Lung function abnormalities in flour mill workers using spirometry. International Journal of Medical Science and Public Health. 5(4): 743-748.

Munn, N.J.; Thomas, S.W. and DeMesquita, S. 1990. Pulmonary Function in Commercial Glass Blowers.Chest.98(4): 871-874.

Rastogi, S.K., Gupta, B. N., Husain, T., Chandra,H., Mathur, N., Pangtey, B.S., Chandra, S.V. and Garg, N. 1991. A cross-sectional study of pulmonary function among workers exposed to multimetals in the glass bangle industry. American Journal of Industrial Medicine. 20 (3): 283-433.
Robertson J. Scientific Glassblowing Safety. Journal of Chemical Health \& Safety. September/October 2007; 25-30

Wintour, N. 2015. The glass industry: recent trends and changes in working conditions and employment relations.Geneva, International Labour Office. 53p. ISBN: 9789221301172; 9789221301189.

Yingratanasuk, T., Seixas, N., Barnhart, S. and Brodkin, D. 2002. Respiratory Health and Silica Exposure of Stone Carvers in Thailand. International Journal of Occupational Environment and Health. 8(4):301-308. DOI:10.1179/107735202800338722.

Zuskin, E., Butkovic, D., Schachter, E.N. and Mustajbegovic, J. 1993. Respiratory function in workers employed in the glassblowing industry. American Journal of Industrial Medicine.23(6):835-44.

\section{How to cite this article:}

Sonia Tewari and Deepa Vinay. 2021. Assessment of Respiratory and Pulmonary Functions of Glass Blowers. Int.J.Curr.Microbiol.App.Sci. 10(01): 2631-2638. doi: https://doi.org/10.20546/ijcmas.2021.1001.306 